\title{
Cost accounting in transport companies
}

\author{
Larisa Gerasimova ${ }^{1, *}$ \\ ${ }^{1}$ Moscow State University of Civil Engineering, Yaroslavskoye shosse, 26, Moscow, 129337, Russia
}

\begin{abstract}
The article shows that the main task of business development related to transport is obtaining of the required financial result while observing cost optimization for efficient management of these expenses. It is noted that among the existing means of optimizing expenditures, the main ones are methods of constant expenditure management, such as control and accounting, planning, as well as a number of measures aimed at reduction of expenses. The utility of detailing expenditures and allocating rationalized costs from them has been substantiated. The problems that hinder the construction of a productive cost management system are noted.
\end{abstract}

\section{Introduction}

In the context of the present market competitiveness depends primarily on the speed of implementation in the company of various innovative technologies and on the ability to offer new services that differ in quality and cost from competitors' services.

It is necessary to reduce the price of the service with certain quality standards in order to maintain and increase in such conditions the set amount of profit [1].

The economy of this time promotes the most efficient implementation cost management in companies. The rate of profit decreases with the growth of competition in the target segment of the market. As a result, the chances of business development are directly dependent on the behavior of costs and the ability to manage them. Rational cost management promotes to prevent unnecessary costs and increase the competitive capacity of enterprises in the market. The implication is that it is impossible without a correct and high-quality cost management system to achieve the indicators required for the implementation of the most important step related to the adoption of investment decisions an assessment of the effectiveness of real investments.

The information provided by an effective cost management system promotes to the most accurate justification of management decisions, as opposed to unpredictable solutions [1-4]. The applicability of the topic is predetermined by the serious need for cost management, as the company, regardless of the type of activity, suffers costs and expenditures. Expenses are the main production factor associated with pricing and profit formation. This factor turns pricing and profit formation planning into the main component of the production management process $[5,6]$. The requirements for successful management of economic activities stipulate a high need for improvement of the proper accounting segment [7].

* Corresponding author: 22969@mail.ru 
It is reasonable, from this point of view, to introduce the search for innovative approaches to the management accounting in the framework of expenditure management.

In the meantime with the development of process approaches to management it becomes clear that estimatation of all the company's expenses only from the position of the market activity final results reflected in the accounting records of income and profit is unreasonable [8-14].

\section{Materials and Methods}

It is necessary to analyze the whole chain of processes related to the company's production and business activities, including intermediate processes, as well as simultaneous monitoring of the location, purpose, volume, efficiency of using any resources.

Let's consider special aspects of use of the management accounting in the transport organizations. To date, the nomenclature of articles of production costs and costs for calculating the prime cost in management accounting is being prepared by transport organizations on the basis of management requirements at various stages of management. In other words, transport company executives must independently take decisions related to this issue. An innovative approach to cost management in length of time displaces the traditional approach. This requires the allocation of a new cost grouping characteristic based on implemented strategies and a systematic approach to business complexities. The purpose of this characteristic is aimed at improving the level of customer satisfaction, the productivity of the used technologies, optimizing the structure of the used resources and the effectiveness of business processes.

A common classification for fixed and variable costs can be erroneous if the question is about rationalizing solutions. And therefore costs need to be separated within a certain time range. The greatest interest in this is the rationalized expenses. An approximate classification of rationalized expenses for management purposes is presented in Table 1.

Table 1. Approximate classification of rationalized expenses for management purposes.

\begin{tabular}{|c|c|c|}
\hline $\begin{array}{c}\text { Company } \\
\text { expenditure }\end{array}$ & $\begin{array}{c}\text { Examples of major } \\
\text { expenditure items }\end{array}$ & Examples of analytical accounts \\
\hline Transactional & $\begin{array}{c}\text { Search of customers, profitable partners and investors. } \\
\text { Guarantees when making deals. Negotiation. Conclusion } \\
\text { of contracts. Expenses for performance of obligations } \\
\text { under contracts. Adaptive unexpected expenses }\end{array}$ \\
\cline { 2 - 4 } & Innovative & $\begin{array}{c}\text { Studies related to research and development. Liquidation } \\
\text { of Funds. Development of innovative technologies }\end{array}$ \\
\cline { 2 - 4 } & Conjunctural & $\begin{array}{c}\text { Expenses due to inflation. Expenses for services related to } \\
\text { mediation. Expenses for incoming resources purchased } \\
\text { from outside organizations. }\end{array}$ \\
& $\begin{array}{c}\text { Expenses for studying market conditions. Costs of } \\
\text { competitors. }\end{array}$ \\
\cline { 2 - 4 } & Expenses for the & $\begin{array}{c}\text { Preventive repairs. Development of activities aimed at } \\
\text { environmental protection measures.Disposal of hazardous } \\
\text { industrial waste }\end{array}$ \\
\cline { 2 - 3 } & $\begin{array}{c}\text { Investments in } \\
\text { human resources }\end{array}$ & $\begin{array}{c}\text { Training of young professionals, staff development. } \\
\text { Expenses related to staff reduction. Expenses necessary to } \\
\text { encourage employees for invention and innovation. } \\
\text { Expenses required to achieve employees' personal } \\
\text { performance indicators. Expenses to achieve the level of } \\
\text { the average wage in the industry }\end{array}$ \\
\hline
\end{tabular}

Let us analyze certain aspects of managing rationalization expenditures. 
According to the author's approach, rationalized costs are appropriate when their occurrence is associated with the growth of indicators and improving the quality of the company's activities. Examples of these indicators are: the growth of the company's operational period simultaneously with the increase of company's market value and market share, quality improvement, security strengthening and public perception of services provided, development of innovative business directions etc.

\section{Results}

It is desirable to carry out expenditure classification within the framework of the conjuncture, innovation, transaction costs, environmental costs, and contributions to human resources.

The chart of accounts for the purposes of transport companies is set out in Table 3.

Table 3. Approximate chart of accounts of the transport company's management accounting associated with cost management of a rationalized character.

\begin{tabular}{|c|c|c|}
\hline \multicolumn{3}{|c|}{ Name } \\
\hline accounts & sub-accounts & analytical account \\
\hline \multirow{5}{*}{$\begin{array}{l}30 \text { Planned } \\
\text { expenses }\end{array}$} & Transactional expenses & Types of expenses \\
\hline & Innovation expenses & \multirow{4}{*}{$\begin{array}{l}\text { Responsibility } \\
\text { Centers. } \\
\text { Innovative projects }\end{array}$} \\
\hline & Conjunctural expenses & \\
\hline & Expenses for the environment & \\
\hline & Human resources & \\
\hline \multirow{5}{*}{$\begin{array}{l}31 \text { Transactional } \\
\text { expenses }\end{array}$} & Business connections & \multirow{5}{*}{$\begin{array}{c}\text { Responsibility } \\
\text { Centers. } \\
\text { Innovative projects }\end{array}$} \\
\hline & Guarantees of transactions & \\
\hline & Business negotiations and conclusion of contracts & \\
\hline & Fulfillment of treaty obligations & \\
\hline & Unexpected expenses & \\
\hline \multirow{3}{*}{32 Innovation } & Expenses for scientific research & \multirow{3}{*}{$\begin{array}{c}\text { Responsibility } \\
\text { Centers. } \\
\text { Innovative projects }\end{array}$} \\
\hline & Liquidation of a Funds & \\
\hline & Venturing & \\
\hline \multirow{3}{*}{$\begin{array}{l}33 \text { Conjunctural } \\
\text { expenses }\end{array}$} & Marketing research & \multirow{3}{*}{$\begin{array}{c}\text { Responsibility } \\
\text { Centers. } \\
\text { Innovative projects }\end{array}$} \\
\hline & Advertising of innovative services & \\
\hline & Intermediary services & \\
\hline \multirow{4}{*}{$\begin{array}{l}34 \text { Expenses for } \\
\text { the environment }\end{array}$} & Repair and maintenance of equipment & \multirow{4}{*}{$\begin{array}{c}\text { Responsibility } \\
\text { Centers. } \\
\text { Innovative projects }\end{array}$} \\
\hline & Measures to environmental protection & \\
\hline & Insurance payments & \\
\hline & Disposal costs & \\
\hline \multirow{4}{*}{$\begin{array}{l}35 \text { Human } \\
\text { resources }\end{array}$} & Expenditure on staff development & \multirow{4}{*}{$\begin{array}{c}\text { Responsibility } \\
\text { Centers. } \\
\text { Innovative projects }\end{array}$} \\
\hline & Encouraging staff to inventions and innovations & \\
\hline & $\begin{array}{c}\text { The cost of achieving personal performance } \\
\text { indicators }\end{array}$ & \\
\hline & Staff reduction expenses & \\
\hline \multirow{5}{*}{$\begin{array}{l}36 \text { Rationalized } \\
\text { expenses }\end{array}$} & Transactional expenses & \multirow{5}{*}{$\begin{array}{c}\text { Responsibility } \\
\text { Centers. } \\
\text { Innovative projects }\end{array}$} \\
\hline & Innovation expenses & \\
\hline & Conjunctural expenses & \\
\hline & Expenses for the environment & \\
\hline & Human resources & \\
\hline \multirow{4}{*}{$\begin{array}{l}37 \text { Deviations of } \\
\text { rationalized } \\
\text { expenses }\end{array}$} & Optimization of internal processes & \multirow{4}{*}{$\begin{array}{c}\text { Responsibility } \\
\text { Centers. } \\
\text { Innovative projects }\end{array}$} \\
\hline & Expenditure on staff development & \\
\hline & Strengthening market positions & \\
\hline & Inflation expenses & \\
\hline
\end{tabular}


It should be noted that in order to manage the rationalized expenses, it is necessary to fix the planned level of expenses, the amount of which is supposed to be accounted for by the debit of account 30 "Planned expenses" in correspondence with the accounts 31-35. The debit of the above listed accounts in this case will reflect the fact of the level of expenses of a rationalized character in correspondence with the accounts: acc.02, acc.05, acc.10, acc.60, acc.66, acc.67, acc.68, acc.69, acc.70, acc.76.

The effect of this accounting should be evident in the ratio of rationalized expenditures under the chart and after the fact, as well as in accounting for and analysis of deviations accounted for separately in Account 37 "Deviations of rationalized expenses".

If there is a negative deviation of expenses (that means an excess of the fact over the chart of accounts), an entry is made on the debit of the acc.37 and the credit of the expense accounts of the rationalized nature. The positive deviation of costs (that means an excess of the chart of accounts over the fact) should be reversed.

\section{Discussions}

Therefore, we identify the accounting of expenses of rationalized nature using the following management accounting tools:

$\checkmark$ target balanced parameters on the basis of which it is recommended to carry out the specification and digitization of targets for critical segments of the company's activities;

$\checkmark$ budget planning carried out on the basis of development of auxiliary budgets that take into account the target parameters and aimed at importing non-financial values into the system of standard budget planning;

$\checkmark$ employee motivation as one of the company's most important resources; the development of motivation is focused on the execution in the long view objectives of the company.

Heads of the company need an objective assessment of prospective indicators. Indicators are the accounting analytical support in the process of making managerial decisions. And also it is necessary to take into account the peculiarities of expenditures and the choice of grouping in the constantly changing conditions of business activities. Only by applying the considered approach to the tasks it is possible to achieve the company's profitability with availability of the necessary resources and their rational use.

\section{Conclusion}

In conclusion, it should be noted that only the correct cost management in the current conditions of an unstable economy and fierce competition will allow to the company to effectively carry out financial and economic activities. The above issues are particularly relevant and need further research.

\section{References}

1. K.U. Kotova, Upravlencheskyu uchet 2, 22 - 34 (2016)

2. S.A. Butler, D. Ghosh, The British Accounting Review 47-1, 33 - 45 (2015)

3. L.N. Gerasimova, Birzha intellektualnoyu sobstvennosti 7, 15-23 (2017)

4. E.S. Panchenko, Planovo-ekonomlcheskiyu otdel 7, 16-44 (2017)

5. A. Chopra, International Journal of Marketing, Financial Services \& Management Research 2-8, 79 - 84 (2013) 
6. R.H. Garrison, E.W. Noreen, P.C. Brewer, Managerial Accounting for Managers (McGraw-Hill Irwin, NY, 2011)

7. L.N. Gerasimova, Auditorskie vedomosti 7, 87-93 (2017)

8. S.A. Butler, D. Ghosh, The British Accounting Review 47-1, 33 - 45 (2015)

9. J. Davison, Accounting and Business Research 45-2, 121-165 (2015)

10. E.N. Dombrovskaya, Upravlencheskyu uchet 5, 10-19 (2016)

11. E.V. Akimova, Planovo-ekonomlcheskiyu otdel 2, 36-44 (2018)

12. L.D. Parker, Critical Perspectives on Accounting 23, 54 - 70 (2012)

13. S.Q. Qu, D.J. Cooper, Accounting, Organizations and Society 36(6), $344-362$ (2011)

14. K.E. Norton, C. de A. Wanderley, Management Accounting Research 33, 15-27 (2016)

15. Y. Konchitchki, The Accounting Review 86-3, 1045 - 1085 (2011)

16. M. Canning, B. O'Dwyer, Accounting, Organizations and Society 54, 1-21 (2016)

17. E.N. Dombrovskaya, I.V. Mamonova, Birzha intellektualnoyu sobstvennosti 14-2, 1524 (2015)

18. L.N. Gerasimova, Uchet. Analiz. Audit 1, 77-81 (2015)

19. T. Schleicher, M. Walter, Accounting and Business Research 45-2, 229 - 255 (2015)

20. L. Kim, Strategic management accounting: Monograph (INFRA-M, Moscow, 2014) 